\section{APEM}

\title{
Using entropy weight, OEC and fuzzy logic for optimizing the parameters during EDM of Al-24 \% $\mathrm{SiC}_{\mathrm{P}} \mathrm{MMC}$
}

\author{
Bhuyan, R.K. ${ }^{a}{ }^{*}$, Routara, B.C. ${ }^{a}$, Parida, A.K. ${ }^{a}$ \\ ${ }^{\mathrm{a}}$ School of Mechanical Engineering, KIIT University, Bhubaneswar, India
}

\begin{abstract}
A B S T R A C T
In this paper the multiple methodologies are used viz. Entropy weight measurement, Overall evaluation criteria (OEC), and fuzzy logic for optimizing the process parameters during Electrical discharge machining (EDM) process of $\mathrm{Al}-24 \% \mathrm{SiC}_{\mathrm{P}}$ metal matrix composite (MMC). Three process parameters like as peak current, pulse on time and flushing pressure are considered as input variables whereas material removal rate, tool wear rate, radial over cut and surface roughness are response variables. Central composite design (CCD) is used as the design of experiment (DoE) for conducting the experiments using different combinations of input variables of three levels for predicting responses. The individual weightage of each response is calculated using the Entropy weight method and normalization of responses were carried out with the same weightage of responses using OEC. Finally fuzzy logic was used to obtain a single numerical index known as the Multi performance characteristics index (MPCI). The Analysis of Variance (ANOVA) was used to find the significances of process parameters on the responses. The second-order mathematical model was developed using response surface methodology for predicting the results. Moreover, a confirmation test was carried out to check the effectiveness of the presented approach.
\end{abstract}

\section{ARTICLE INFO}

Keywords:

Electrical discharge machining

Aluminium MMC

Entropy weight measurement

Overall evaluation criteria

Fuzzy logic

*Corresponding author: rajesh_bhuyan001@ rediffmail.com (Bhuyan, R.K.)

Article history:

Received 15 April 2015

Revised 14 October 2015

Accepted 19 October 2015 


\section{APEM}

\title{
Uporaba utežene entropijske metode, metode OEC in mehke logike za optimizacijo parametrov med elektroerozijsko obdelavo Al-24 \% SiC $\mathrm{S}_{\mathrm{p}}$ kompozita s kovinsko osnovo
}

\author{
Bhuyan, R.K. ${ }^{\mathrm{a},{ }^{*}}$, Routara, B.C. ${ }^{\mathrm{a}}$, Parida, A.K. ${ }^{\mathrm{a}}$ \\ ${ }^{\text {a }}$ School of Mechanical Engineering, KIIT University, Bhubaneswar, India
}

\section{POVZETEK}

$\mathrm{V}$ prispevku smo uporabili več pristopov za optimizacijo procesnih parametrov pri elektroerozijski obdelavi (EDM) kompozita s kovinsko osnovo (MMC) $\mathrm{Al}-24 \% \mathrm{SiC}$, in sicer uteženo entropijsko metodo, metodo splošne ocenitve kriterijev (OEC) in mehko logiko. Vhodne spremenljivke so bile največji tok, čas trajanja impulza in tlak dielektrične tekočine, izhodne oziroma odzivne spremenljivke pa stopnja odvzema materiala, obraba orodja, radialni overcut in hrapavost površine. Uporabljena je bila centralna kompozitna shema (CD) kot načrtovanje eksperimentov (DoE) za izvedbo preizkusov z različnimi kombinacijami vrednosti vhodnih spremenljivk v treh nivojih. Utežen odziv za vsako izhodno spremenljivko je bil izračunan s pomočjo utežene entropijske metode, normalizacija izhodov pa je bila izvedena z enakimi utežmi z uporabo metode OEC. Na koncu je bila uporabljena mehka logika, s čimer je bil dobljen posamezni numerični indeks, znan kot indeks zmogljivosti več značilnosti (MPCI). Za analizo vplivnosti procesnih parametrov na izhodne spremenljivke smo uporabili analizo variance (ANOVA). Z metodo odzivnih površin smo razvili matematični model drugega reda s katerim smo napovedovali vrednosti odzivov. Narejen je bil še potrditveni test za preverjanje učinkovitosti predstavljenega pristopa.
\end{abstract}

\section{PODATKI O ČLANKU}

Ključne besede:

Electrical discharge machining Aluminijev MMC Utežena entropijska metoda Splošna ocenitev kriterijev Mehka logika

*Kontaktna oseba: rajesh_bhuyan001@ rediffmail.com (Bhuyan, R.K.)

Zgodovina članka:

Prejet 15. aprila 2015

Popravljen 14. oktobra 2015

Sprejet 19. oktobra 2015 


\section{References}

[1] Liu, J.W., Yue, T.M., Guo, Z.N. (2013). Grinding-aided electrochemical discharge machining of particulate reinforced metal matrix composites, The International Journal of Advanced Manufacturing Technology, Vol. 68, No. 9, 2349-2357, doi: 10.1007/s00170-013-4846-8.

[2] Muthukrishnan, N., Davim, J.P. (2011). An investigation of the effect of work piece reinforcing percentage on the mach inability of Al-SiC metal matrix composites, Journal of Mechanical Engineering Research, Vol. 3, No. 1, 15-24.

[3] Ji, R., Liu, Y., Zhang, Y., Cai, B., Ma, J., Li, X. (2012). Influence of dielectric and machining parameters on the process performance for electric discharge milling of SiC ceramic, The International Journal of Advanced Manufacturing Technology, Vol. 59, No. 1, 127-136, doi: 10.1007/s00170-011-3493-1.

[4] Tang, L., Du, Y.T. (2013). Experimental study on green electrical discharge machining in tap water of Ti-6Al-4V and parameters optimization, The International Journal of Advanced Manufacturing Technology, Vol. 70, No.1, 469-475, doi: 10.1007/s00170-013-5274-5.

[5] Kohli, A., Wadhwa, A., Virmani, T., Jain, U. (2012). Optimization of material removal rate in electrical discharge machining using fuzzy logic, World Academy of Science Engineering and Technology, Vol. 6, No. 12, 1674-1679.

[6] Mir, M.J., Sheikh, K., Singh, B., Malhotra, N. (2012). Modelling and analysis of machining parameters for surface roughness in powder mixed EDM using RSM approach, International Journal of Engineering, Science and Technology, Vol. 4, No. 3, 45-52, doi: 10.4314/ijest.v4i3.3.

[7] Karthikeyan, R., Lakshmi Narayanan, P.R, Naagarazan, R.S. (1999). Mathematical modelling for electric discharge machining of aluminium-silicon carbide particulate composites, Journal of Materials Processing Technolgy, Vol. 87, No. 1-3, 59-63, doi:10.1016/S0924-0136(98)00332-X.

[8] Singh, S. (2012). Optimization of machining characteristics in electric discharge machining of $6061 \mathrm{Al}^{-} \mathrm{Al}_{2} \mathrm{O}_{3} \mathrm{p} / 20 \mathrm{P}$ composites by grey relational analysis, The International Journal of Advanced Manufacturing Technology, Vol. 63, No. 9, 1191-1202, doi: 10.1007/s00170-012-3984-8.

[9] Shukla, A.K., Raghu, T., Rajesham, S., Balasundar, I. (2014). Analysis of significant parameters influencing formability of titanium alloy by using over all evaluation criteria and new matrix model based on Taguchi method, Transactions of the Indian Institute of Metals, Vol. 67, No. 5, 721-730, doi: 10.1007/s12666-014-0378-7.

[10] Aliakbari, E., Baseri, H. (2012). Optimization of machining parameters in rotary EDM process by using the Taguchi method, The International Journal of Advanced Manufacturing Technology, Vol. 62, No. 9, 1041-1053, doi: $10.1007 / \mathrm{s} 00170-011-3862-9$.

[11] Kiran, U.V. (2010). Product optimization of graters using Taguchi technique, Asian Journal of Home Science, Vol. 5, No. 1, 128-130.

[12] Shahbazian, A., Navarchian, A.H., Pourmehr, M. (2009). Application of Taguchi method to investigate the effects of process factors on the performance of batch emulsion polymerization of vinyl chloride, Journal of Applied Polymer Science, Vol. 113, No. 5, 2739-2746, doi:10.1002/app.30194.

[13] Chia, Y.Y., Ridhuan, A.S., Dino, I., Ahmida, A., Khiew, P.S. (2012). Optimization of process factors in super capacitor fabrication using the genetic algorithm to optimize Taguchi signal-to-noise ratios, International Journal of Engineering Science and Innovative Technology, Vol. 1, No. 2, 135-149.

[14] Haddad, M.B., Ebrahimi, N.G. (2006). Effect of radiation on the properties of UHMWPE/PET composite, Iranian Polymer Journal, Vol. 15, No. 3, 195-205.

[15] Jangra, K., Grover, S., Aggarwal, A. (2012). Optimization of multi machining characteristics in WEDM of WC$5.3 \%$ Co composite using integrated approach of Taguchi GRA and entropy method, Frontiers of Mechanical Engineering, Vol. 7, No. 3, 288-299, doi: 10.1007/s11465-012-0333-4.

[16] Sivasankar, S., Jeyapal, R. (2012). Application of grey entropy and regression analysis for modelling and prediction on tool materials performance during EDM of hot pressed $\mathrm{ZrB}_{2}$ at different duty cycles, Procedia Engineering, Vol. 38, 3977-3991, doi: 10.1016/i.proeng.2012.06.455.

[17] Majhi, S.K., Mishra, T.K., Pradhan, M.K., Soni, H. (2014). Effect of machining parameters of AISI D2 tool steel on electro discharge machining, International Journal of Current Engineering and Technology, Vol. 4, No. 1, 19-23.

[18] Puhan, D., Mahapatra, S.S., Sahu, J., Das, L. (2013). A hybrid approach for multi-response optimization of nonconventional machining on AlSiC MMC, Measurement, Vol. 46, No. 9, 3581-3592, http:/10.1016/j.measurement. $\underline{2013.06 .007 .}$

[19] Majumder, A. (2013). Process parameter optimization during EDM of AISI 316 LN stainless steel by using fuzzy based multi-objective PSO, Journal of Mechanical Science and Technology, Vol. 27, No. 7, 2143-2151, doi: $10.1007 / \mathrm{s}^{2} 2206^{\prime} 013^{\prime} 0524 \mathrm{x}$.

[20] Khalid, N.E.A., Bakar, N.A., Ismail, F.Sh., Dout, N.S.M. (2011). Multi-objective optimization using fuzzy evolutionary strategies optimization, International Journal of Systems Applications, Engineering \& Development, Vol. 5, No. 6, 728-737.

[21] Laxman, J., Raj, K.G. (2014). Modelling and analysis of EDM process parameters using Taguchi technique and fuzzy based modelling, International Journal of Advanced Mechanical Engineering, Vol. 4, No. 5, 473-480.

[22] Sengottuvel, P., Satishkumar, S., Dinakaran, D. (2013). Optimization of multiple characteristics of EDM parameters based on desirability approach and fuzzy modeling, Procedia Engineering, Vol. 64, 1069-1078, doi: 10.1016/j.proeng.2013.09.185.

[23] Rodic, D., Gostimirovic, M., Kovac, P., Radovanovic, M., Savkovic, B. (2014). Comparison of fuzzy logic and neural network for modelling surface roughness in EDM, International Journal of Recent Advances in Mechanical Engineering, Vol. 3, No. 3, 69-78, doi: 10.14810/ijmech.2014.3306.

[24] Rao, P.S., Prasad, K. E., Reddy, B.S. (2011). Fuzzy modelling for electrical discharge machining of aluminum alloy, International Journal of Research and Reviews in Applied Sciences, Vol. 9, No. 1, 112-125. 
[25] Pradeep K.J., Giriprasad, C.R. (2013). Investigation on application of fuzzy logic concept for evaluation of electric discharge machining characteristics while machining aluminium silicon carbide composite, International Journal of Science, Engineering and Technology Research, Vol. 2, No. 10, 1804-1809.

[26] Bhuyan, R.K., Routara, B.C., Parida, A.K. (2015). Parametric optimization during EDM of Al-SiCp metal matrix composite using fuzzy logic, International Conference on Electrical, Electronics, Signals, Communication and Optimization (EESCO), IEEE, Vol. 5, 1-6, doi: 10.1109/EESC0.2015.7253834.

[27] Li, X., Wang, K., Liu, L., Xin, J., Yang, H., Gao, C. (2011). Application of the entropy weight and TOPSIS method in safety evaluation of coal mines, Procedia Engineering, Vol. 26, 2085-2091, doi: 10.1016/j.proeng.2011.11.2410.

[28] Sałabun, W. (2013). The mean error estimation of TOPSIS method using a fuzzy reference models, Journal of Theoretical and Applied Computer Science, Vol. 7, No. 3, 40-50.

[29] Li, N., Wang, Y. (2012). Measuring the development level of Chinese regional service industry: An empirical analysis based on entropy weight and TOPSIS, World Academy of Science, Engineering and Technology, Vol. 6, No. 8, 133-139.

[30] Sahoo, A.K., Orra, K., Routra, B.C. (2013). Application of response surface methodology on investigating flank wear in machining hardened steel using PVD TiN coated mixed ceramic insert, International Journal of Industrial Engineering Computations, Vol. 4, No. 4, 469-478, doi: 10.5267/j.ijiec.2013.07.001.

[31] Shandilya, P., Jain, P.K, Jain, N.K. (2012). Parametric optimization during wire electrical discharge machining using response surface methodology, Procedia Engineering, Vol. 38, 2371-2377, doi: 10.1016/i.proeng.2012. $\underline{06.283}$. 